\title{
Zatrudnienie a intensywność rolnictwa państw Unii Europejskiej
}

\section{Employment and Intensity of Agriculture of European Union Countries}

\begin{abstract}
Synopsis. Celem artykułu jest omówienie zatrudnienia w kontekście intensywności w rolnictwie państw Unii Europejskiej na podstawie wybranych cech. Analizę przeprowadzono dla 2016 roku. Badanie przeprowadzono za pomocą analizy skupień. Do analizy przyjęto następujące cechy diagnostyczne: udział ludności czynnej zawodowo w rolnictwie z niskim poziomem wykształcenia w całkowitej liczbie ludności czynnej zawodowo (\%), udział ludności zatrudnionej w rolnictwie w ludności zatrudnionej ogółem (\%), produktywność pracy w rolnictwie (EUR/AWU), udział wartości dodanej dostarczanej przez sektor rolniczy (\%), udział użytków rolnych zarządzanych przez gospodarstwa o dużej intensywności w użytkach rolnych ogółem (\%) oraz średnia ekonomiczna wielkość gospodarstw (SO/gospodarstwo w EUR). W wyniku zastosowania analizy skupień podzielono badane państwa na cztery grupy. Zgodnie z wynikami w państwach o wysokim poziomie zatrudnienia w rolnictwie zwykle mniejszy jest udział wartości dodanej dostarczanej przez sektor rolniczy. Natomiast w państwach o niższym udziale zatrudnionych w rolnictwie intensywność rolnictwa jest $\mathrm{z}$ reguły większa.
\end{abstract}

Słowa kluczowe: zatrudnienie, intensywność rolnictwa, państwa Unii Europejskiej

\begin{abstract}
The objective of the article is to discuss employment in the context of the agriculture intensity in European Union countries based on selected features. The analysis was conducted for 2016. Research was examined using the cluster analysis. The following diagnostic features were used for the analysis: share of working population in agriculture with low educational attainment in total working population (\%), share of working population in agriculture in total working population $(\%)$, labour productivity in agriculture (EUR/AWU), distribution of GVA by primary sector (\%), share of UAA managed by farms with high input intensity per ha (\%), average economic farm size (SO/holding in EUR). As a result of the cluster analysis, the examined regions were divided into four groups. According to the results, in countries with high levels of employment in agriculture, the share of added value provided by the agricultural sector is usually smaller. However, in countries with a lower share of people employed in agriculture, the intensity of agriculture is usually higher.
\end{abstract}

Key words: employment, agriculture intensity, European Union countries

JEL Classification: E24, J24, J43

\section{Wprowadzenie}

Tradycyjnie intensywność produkcji rolnej uzależniano od poniesionych nakładów. Rolnictwo intensywne na obszarach wiązało się z dużymi nakładami na jednostkę powierzchni upraw, bądź jednostkę hodowlaną oraz osiąnnięciem w związku z tym

${ }^{1}$ dr, Katedra Polityki Ekonomicznej i Regionalnej Politechnika Koszalińska, ul. Kwiatkowskiego 6E,

75-343 Koszalin, e-mail: luiza.ossowska@tu.koszalin.pl

${ }^{2}$ dr, Katedra Polityki Ekonomicznej i Regionalnej Politechnika Koszalińska, ul. Kwiatkowskiego 6E,

75-343 Koszalin,e-mail: dorota.janiszewska@tu.koszalin.pl 
wysokich przeciętnych plonów roślin i efektów hodowli zwierząt. Nadal w zależności od proporcji nakładów pracy i kapitału wyróżnia się intensywną gospodarkę rolną pracochłonną oraz intensywną gospodarkę rolną kapitałochłonną (Skrzypczak, 2002). Obecnie intensywność produkcji rolniczej określa się zróżnicowanymi wskaźnikami, odnoszącymi się m.in. do warunków strukturalno-organizacyjnych, i ekonomicznych (Głowacki, 2002; Kasztelan, 2008).

Należy również dodać, że według rozwiniętej w latach 30 . XX w. przez Fishera, Clarka i Fourastiego koncepcji trójsektorowego podziału gospodarki wraz z rozwojem gospodarczym maleje znaczenie sektora rolnego (cyt. za: Kwiatkowski 1980). Stąd jednym z głównych problemów rolnictwa wielu krajów jest nadmierne zatrudnienie (Szczukocka 2012).

Państwa Unii Europejskiej realizują Wspólną Politykę Rolną, wśród efektów której wymienia się: zwiększenie wydajności rolnictwa, a także odpowiedni poziom życia ludności (Bielecki 2010). W związku ze specyfiką działalności rolniczej wsparcie udzielane w ramach prowadzonej Wspólnej Polityki Rolnej ma na celu m.in. modernizacje i restrukturyzację sektora rolnego, a także zróżnicowanie aktywności na obszarach wiejskich (Sienkiewicz 2009). Sa to działania związane z poprawą intensywności przy jednoczesnych zabiegach przeciwdziałających nadmiernemu zatrudnieniu w rolnictwie.

\section{Cele i metody badań}

Celem badań jest omówienie zatrudnienia w kontekście intensywności rolnictwa w państwach Unii Europejskiej na podstawie wybranych cech. Uwzględniając przesłanki merytoryczne i dostępność danych do analizy przyjęto następujące cechy diagnostyczne:

- udział ludności czynnej zawodowo $\mathrm{w}$ rolnictwie $\mathrm{z}$ niskim poziomem wykształcenia w całkowitej liczbie ludności czynnej zawodowo (\%),

- udział ludności zatrudnionej w rolnictwie w ludności zatrudnionej ogółem (\%),

- produktywność pracy w rolnictwie (EUR/AWU),

- udział wartości dodanej dostarczanej przez rolnictwo (\%),

- udział użytków rolnych zarządzanych przez gospodarstwa o dużej intensywności na ha w użytkach rolnych ogółem (\%),

- średnia ekonomiczna wielkość gospodarstw (SO/gospodarstwo w EUR).

Dane, na podstawie których dokonano analizy pochodzą z publikacji Eurostatu: Agriculture, forestry and fishery statistics - edycji 2017 (Agriculture..., 2017) oraz publikacji Komisji Europejskiej: Cap context indicators 2014-2020 (European Commission..., 2017). Analizę zróżnicowania badanego zjawiska przeprowadzono dla roku $2016^{3}$.

Zróżnicowanie państw Unii Europejskiej pod względem zatrudnienia w rolnictwie oraz intensywności rolnictwa określono za pomocą analizy skupień. W badaniach posłużono się tzw. odległością euklidesową która rozumiana jako funkcja podobieństwa, pozostaje w ścisłym związku z geometryczną interpretacją obserwacji wielowymiarowej.

\footnotetext{
${ }^{3}$ Z uwagi na brak danych dla roku 2016, w zakresie udziału użytków rolnych zarządzanych przez gospodarstwa o dużej intensywności na ha w użytkach rolnych ogółem, przyjęto do analizy dane z 2015 roku, natomiast dla średniej ekonomicznej wielkości gospodarstw (SO/gospodarstwo w EUR) przyjęto dane dla 2013 roku.
} 
Odległość euklidesową obliczono według następującej formuły (Parysek, Wojtasiewicz 1979):

$$
d_{i k}=\sqrt{\sum_{j=1}^{m}\left(x_{i j}-x_{k j}\right)^{2}},
$$

gdzie: $\mathrm{d}_{\mathrm{ik}}$ - odległość pomiędzy i-tym i k-tym obiektem (dla i $\left.=\mathrm{k}=1,2, \ldots, \mathrm{n}\right), \mathrm{x}_{\mathrm{ij}}$ - wartość j-tej zmiennej dla i-tego obiektu (dla $\mathrm{j}=1,2, \ldots, \mathrm{m}), \mathrm{x}_{\mathrm{kj}}$ - wartość $\mathrm{j}$-tej zmiennej dla k-tego obiektu.

Do obliczeń wykorzystano zmienne standaryzowane według następującej formuły:

$$
z_{i j}=\frac{x_{i j}-\bar{x}_{j}}{s_{j}},(\mathrm{i}=1,2, \ldots, \mathrm{n}, \mathrm{j}=1,2, \ldots, \mathrm{m})
$$

gdzie: $\bar{x}_{j}$ - średnia arytmetyczna dla j-tej cechy prostej, $s_{j}$ - odchylenie standardowe.

Funkcja podobieństwa stanowi podstawę przeprowadzania operacji tworzenia skupień na zasadzie grupowania. W pracy wykorzystano metodę tworzenia skupień J.H. Warda, polegającą na łączeniu tych skupień, które jako całość zapewniają minimum sumy kwadratów odległości od środka ciężkości nowego skupienia, które tworzą (Parysek, Wojtasiewicz 1979).

\section{Wyniki}

W państwach Unii Europejskiej udział ludności czynnej zawodowo w rolnictwie o niskim poziomie wykształcenia w całkowitej liczbie ludności czynnej zawodowo charakteryzuje się znacznym zróżnicowaniem ${ }^{4}$. Wartości tego wskaźnika wahają się od 4,1\% do 90,2\%, przy średniej dla państw Unii Europejskiej 36,1\% (rys. 1). Najniższe wartości odnotowano w Czechach (4,1\%), na Słowacji (5,3\%), Litwie (10,9\%) w Niemczech $(13,0 \%)$ oraz Polsce $(15,6 \%)$. Natomiast zdecydowanie wyższe wartości w zakresie analizowanego wskaźnika odnotowano na Malcie $(90,2 \%)$, w Portugalii (87,6\%), Hiszpanii (72,5\%), Grecji $(64,2 \%)$ oraz na Cyprze $(61,5 \%)$.

Udział ludności pracującej w rolnictwie w ludności pracującej ogółem charakteryzuje się mniejszym zróżnicowaniem niż wykształcenie. Wartości w tym przypadku wahają się od $0,9 \%$ do $22,5 \%$, przy średniej dla wszystkich państw Unii Europejskiej 4,6\% (rys. 2). Najniższe wartości w zakresie badanej cechy odnotowano w Luksemburgu $(0,9 \%)$, na Malcie $(1,0 \%)$, w Wielkiej Brytanii $(1,0 \%)$, Belgii $(1,2 \%)$ oraz Niemczech $(1,2 \%)$. Wyższy udział zatrudnienia odnotowano natomiast w Rumunii (22,5\%), Grecji (11,9\%), Polsce $(10,0 \%)$, na Litwie $(6,9 \%)$ oraz w Portugalii $(6,4 \%)$.

W państwach Unii Europejskiej produktywność pracy w rolnictwie waha się od 4,3 tys. EUR/AWU do 72,3 tys. EUR/AWU przy średniej dla wszystkich państw 19,2 tys. EUR/AWU (rys. 3). Najniższe wartości w zakresie badanego wskaźnika odnotowano w Polsce (4,3 tys. EUR/AWU), na Łotwie (4,6 tys. EUR/AWU), Chorwacji (5,3 tys.

\footnotetext{
${ }^{4} \mathrm{~W}$ przypadku Luksemburga wystapił brak danych.
} 
EUR/AWU), Rumunii (5,3 tys. EUR/AWU) oraz Słowenii (5,8 tys. EUR/AWU). Zdecydowanie wyższą produktywność pracy w rolnictwie odnotowano w takich państwach jak: Holandia (72,3 tys. EUR/AWU), Belgia (37,1 tys. EUR/AWU), Dania (34,8 tys. EUR/AWU), Francja (33,5 tys. EUR/AWU) oraz Wielka Brytania (32,5 tys. EUR/AWU).
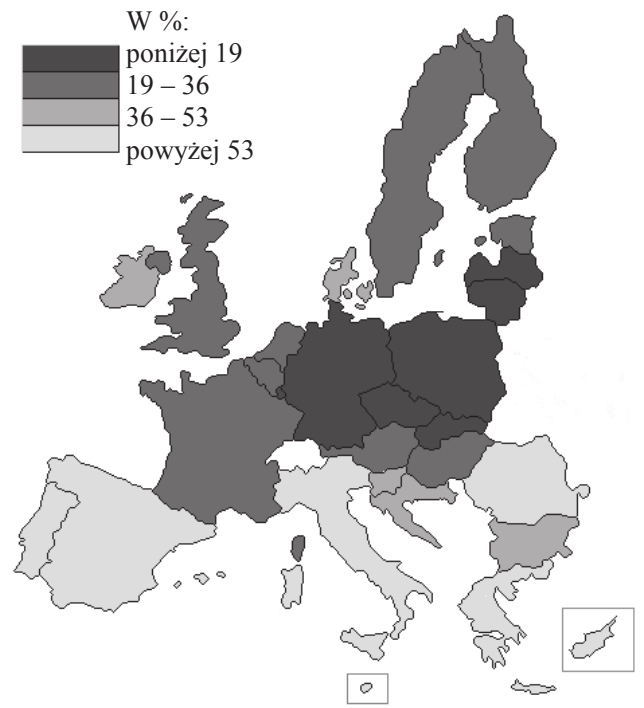

Rys 1. Udział ludności czynnej zawodowo w rolnictwie $\mathrm{z}$ niskim poziomem wykształcenia w całkowitej liczbie ludności czynnej zawodowo w 2016 roku (\%)

Fig 1. Share of working population in agriculture with low educational attainment in total working population in $2016(\%)$
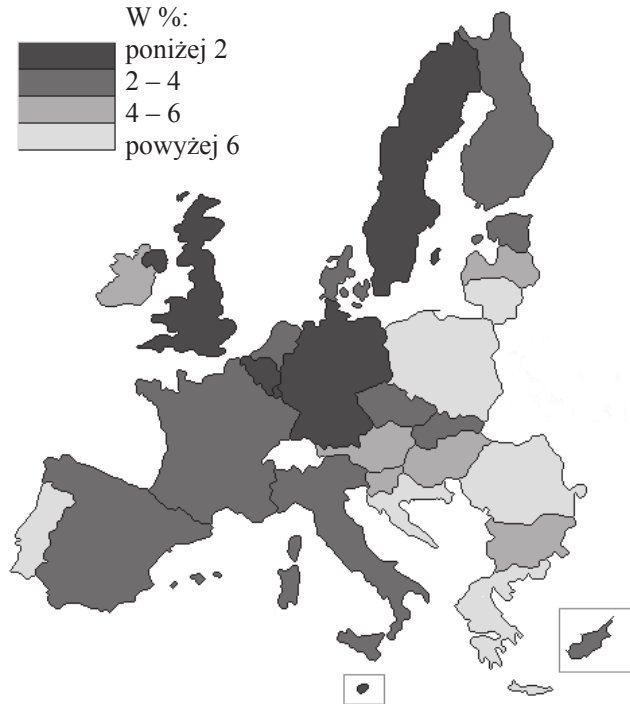

Rys 2. Udział ludności zatrudnionej w rolnictwie w ludności zatrudnionej ogółem w 2016 roku (\%)

Fig 2. Share of working population in agriculture in total working population in $2016(\%)$

Źródło: Obliczenia własne na podstawie: European Commission (2017), Cap context indicators 20142020, Agriculture and Rural Development s. 56.

Źródło: Obliczenia własne na podstawie:

Agriculture, forestry and fishery statistics -2017

edition (2017), Eurostat, Luxemburg, s. 33.

Udział wartości dodanej dostarczanej przez sektor rolniczy w państwach Unii Europejskiej charakteryzuje się małym zróżnicowaniem. Wartości analizowanego wskaźnika wahają się od $0,3 \%$ do $4,7 \%$, przy średniej dla wszystkich państw Unii Europejskiej 2,3\% (rys. 4). Najwyższe wartości odnotowano w Bułgarii (4,7\%), na Węgrzech (4,4\%), w Rumunii (4,3\%), Chorwacji (4,1\%) oraz Grecji (4,0\%). Natomiast najniższe wartości występują w Luksemburgu (0,3\%), Wielkiej Brytanii $(0,6 \%)$, Niemczech (0,6\%), Belgii $(0,7 \%)$ oraz Irlandii $(1,0 \%)$.

W odniesieniu do udziału użytków rolnych zarządzanych przez gospodarstwa o dużej intensywności odnotowano znaczne zróżnicowanie w państwach Unii Europejskiej. Wartości badanej cechy wahają się od 4,6\% do 88,7\% przy średniej dla wszystkich państw $31,0 \%$ (rys. 5). Najniższe wartości odnotowano w Bułgarii (4,6\%), Rumunii (4,8\%), Estonii $(8,2 \%)$ oraz Łotwie $(10,0 \%)$. Natomiast zdecydowanie wyższe wyniki odnotowano 
w Holandii $(88,7 \%)$, Belgii $(73,8 \%)$, Niemczech $(57,8 \%)$, Luksemburgu $(54,6 \%)$, na Malcie $(54,4 \%)$ oraz we Francji $(51,4 \%)$.

W państwach Unii Europejskiej również ekonomiczna wielkość gospodarstw jest znacznie zróżnicowana, wartości w tym zakresie wahają się od 3,3 SO/gospodarstwo wEUR do 303,8 SO/gospodarstwo w EUR, przy średniej dla całego badanego obszaru 72,9 $\mathrm{SO} /$ gospodarstwo w EUR (rys. 6.). Najniższe wartości w zakresie badanej cechy odnotowano w Rumunii (3,3, SO/gospodarstwo w EUR), na Malcie (10,3 SO/gospodarstwo w EUR), Litwie (11,2 SO/gospodarstwo w EUR), Węgrzech (11,4 SO/gospodarstwo w EUR) oraz w Grecji (11,4 SO/gospodarstwo). Natomiast zdecydowanie większe wartości odnotowano w Holandii (303,8 SO/gospodarstwo w EUR), Danii (246,7 SO/gospodarstwo w EUR), Belgii (222,6 SO/gospodarstwo w EUR), Czechach (169,4 SO/gospodarstwo w EUR) oraz Niemczech (162,3 SO/gospodarstwo w EUR).

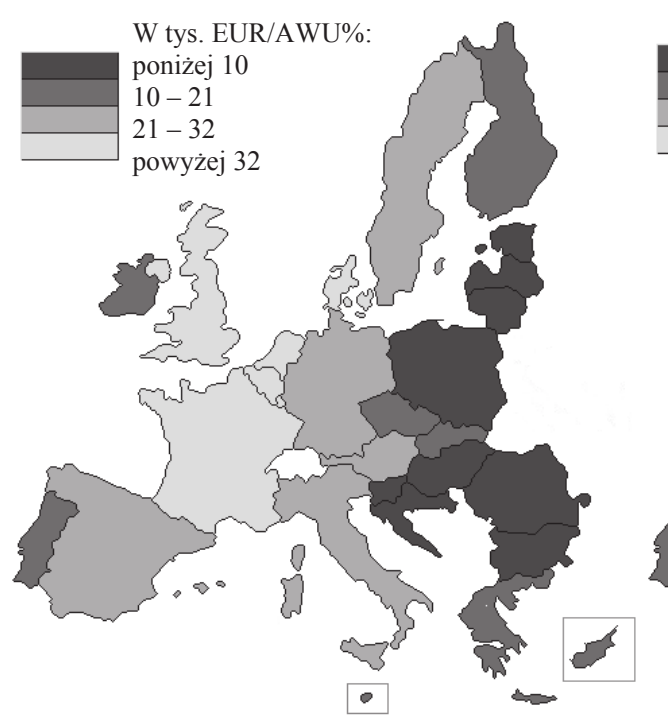

Rys. 3. Produktywność pracy w rolnictwie w 2016 roku (EUR/AWU)

Fig 3. Labour productivity in agriculture in 2016 (EUR/AWU)

Źródło: Obliczenia własne na podstawie: European Commission (2017), Cap context indicators 20142020, Agriculture and Rural Development, s. 49.

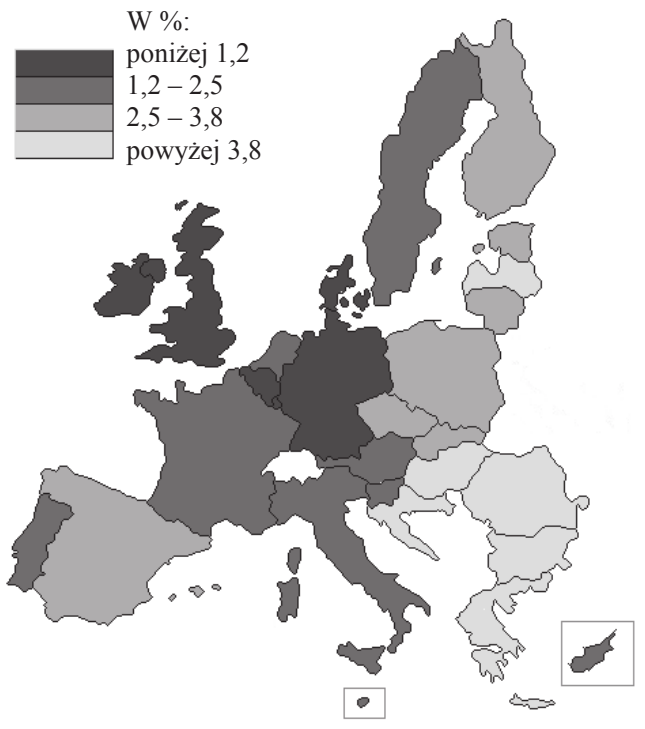

Rys. 4. Udział wartości dodanej dostarczanej przez sektor pierwszy w 2016 roku (\%)

Fig 4. Distribution of GVA by primary sector in $2016(\%)$

Źródło: Obliczenia własne na podstawie: European Commission (2017), Cap context indicators 20142020, Agriculture and Rural Development, s. 44.

Uwzględniając wybrane wskaźniki i stosując metodę wielowymiarową - analizę skupień - badane państwa Unii Europejskiej podzielno na cztery grupy zróżnicowane pod względem zatrudnienia i intensywności w rolnictwie (tab. 1., rys. 7). Grupę I utworzyło osiem państw tj.: Belgia, Dania, Niemcy, Francja, Luksemburg, Holandia, Szwecja oraz Wielka Brytania. Cechą charakterystyczną państw skupionych w tej grupie jest najwyższa spośród wszystkich grup produktywność pracy w rolnictwie, która ukształtowała się na poziomie średnio 37,5 tys. EUR/AWU, przewyższając prawie dwukrotnie średnią dla 
całego badanego obszaru. Ponadto w państwach tej grupy odnotowano również najwyższy udział użytków rolnych zarządzanych przez gospodarstwa o dużej intensywności, który wniósł średnio 55,2\%. W grupie tej odnotowano również najwyższą ekonomiczną wielkość gospodarstw (średnio 174,3 SO/gospodarstwo w EUR), która przewyższyła średnią dla całego badanego obszaru ponad 2,5 krotnie. Warto podkreślić, iż państwa tej grupy charakteryzowały się ponadto najniższym udziałem zatrudnienia w rolnictwie, kształtującym się na poziomie $1,6 \%$ oraz najniższym udziałem wartości dodanej dostarczanej przez sektor pierwszy gospodarki (zaledwie 1,0\%).

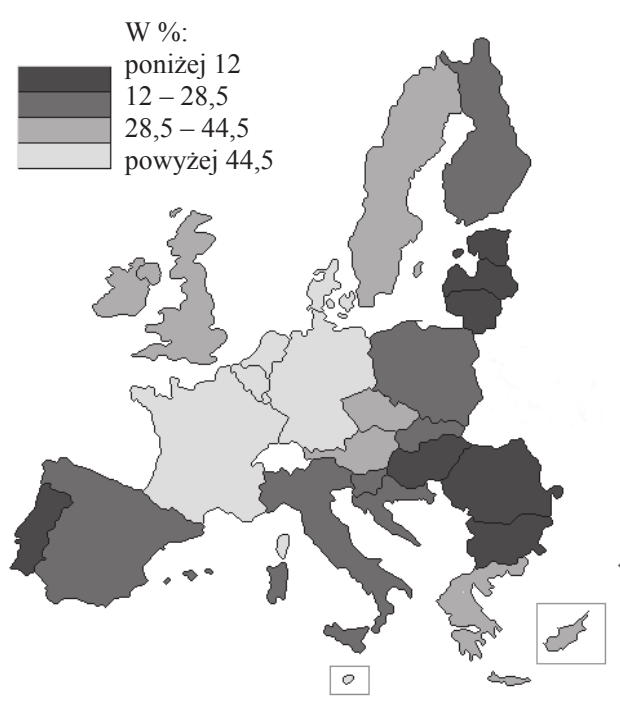

Rys. 5. Udział użytków rolnych zarządzanych przez gospodarstwa o dużej intensywności na ha w użytkach rolnych ogółem w 2015 roku (\%)

Fig. 5. Share of UAA managed by farms with high input intensity per ha in 2015 (\%)

Źródło: Obliczenia własne na podstawie: European Commission [2017], Cap context indicators 20142020, Agriculture and Rural Development, s. 140.
W SO/gospodarstwo w EUR:

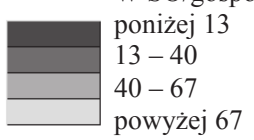

$13-40$

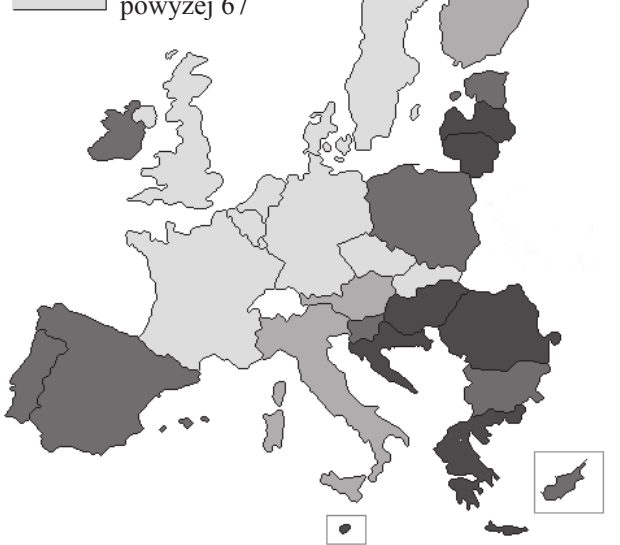

Rys. 6. Średnia ekonomiczna wielkość gospodarstw (SO/gospodarstwo w EUR) w 2013 roku

Fig. 6. Average economic farm size in 2013 (SO/holding in EUR)

Źródło: Obliczenia własne na podstawie: European Commission [2017], Cap context indicators 2014 2020, Agriculture and Rural Development, s. 70.

Grupę II podobnie jak I również utworzyło osiem państw tj.: Bułgaria, Grecja, Chorwacja, Łotwa, Litwa, Węgry, Polska oraz Rumunia. Państwa tej grupy charakteryzują się najwyższym spośród pozostałych grup udziałem zatrudnienia w rolnictwie, który ukształtował się na poziomie $9,2 \%$ przekraczając ponad dwukrotnie średnią dla całego badanego obszaru. Ponadto $\mathrm{w}$ grupie tej odnotowano również wysoki udział wartości dodanej dostarczanej przez pierwszy sektor. Dodatkowo w państwach tej grypy odnotowano najniższą wśród reszty grup produktywność pracy w rolnictwie, która ukształtowała się na poziomie 6,7 tys. EUR/AWU. Również w przypadku udziału użytków rolnych zarządzanych przez gospodarstwa o dużej intensywności odnotowano najniższą wartość, która ukształtowała się na poziomie $14,0 \%$, będąc ponad dwukrotnie niższą niż średnia dla wszystkich państw UE. Najniższą wartość w porównaniu z pozostałymi grupami odnotowano także w zakresie ekonomicznej wielkości gospodarstw, która w tej klasie osiagnęła poziom 11,3 SO/gospodarstwo w EUR. Udział ludności pracującej 
w rolnictwie o niskim wykształceniu okazał się zbliżony do wartości średniej dla całego obszaru i wyniósł $35,1 \%$.

Tabela 1. Zróżnicowanie państw UE pod względem wskaźników charakteryzujących zatrudnienie i intensywność w rolnictwie - wskaźniki według poszczególnych grup

Table 1. Diversification of EU member states in terms of indicators characterizing the employment and intensity in agriculture - indicators by typological groups

\begin{tabular}{|c|c|c|c|c|c|}
\hline Wyszczególnienie & Grupa I & Grupa II & Grupa III & Grupa IV & Ogółem \\
\hline $\begin{array}{l}\text { Udział ludności czynnej zawodowo w rolnictwie z } \\
\text { niskim poziomem wykształcenia w całkowitej } \\
\text { liczbie ludności czynnej zawodowo }(\%)\end{array}$ & 23,8 & 35,1 & 23,7 & 74,6 & 36,1 \\
\hline $\begin{array}{l}\text { Udział ludności zatrudnionej w rolnictwie w } \\
\text { ludności zatrudnionej ogółem (\%) }\end{array}$ & 1,6 & 9,2 & 3,4 & 3,6 & 4,6 \\
\hline Produktywność pracy w rolnictwie (EUR/AWU) & 37498,9 & 6698,3 & 13108,7 & 18420,0 & 19194,2 \\
\hline $\begin{array}{l}\text { Udział wartości dodanej dostarczanej przez sektor } \\
\text { pierwszy (\%) }\end{array}$ & 1,0 & 3,9 & 2,3 & 2,1 & 2,3 \\
\hline $\begin{array}{l}\text { Udział użytków rolnych zarządzanych przez } \\
\text { gospodarstwa o dużej intensywności na ha w } \\
\text { użytkach rolnych ogółem }(\%)\end{array}$ & 55,2 & 14,0 & 23,6 & 29,7 & 31,0 \\
\hline $\begin{array}{l}\text { Średnia ekonomiczna wielkość gospodarstw } \\
\text { (SO/gospodarstwo w EUR) }\end{array}$ & 174,3 & 11,3 & 62,0 & 24,4 & 72,9 \\
\hline Liczba jednostek & 8 & 8 & 7 & 5 & 28 \\
\hline
\end{tabular}

Źródło: obliczenia własne.

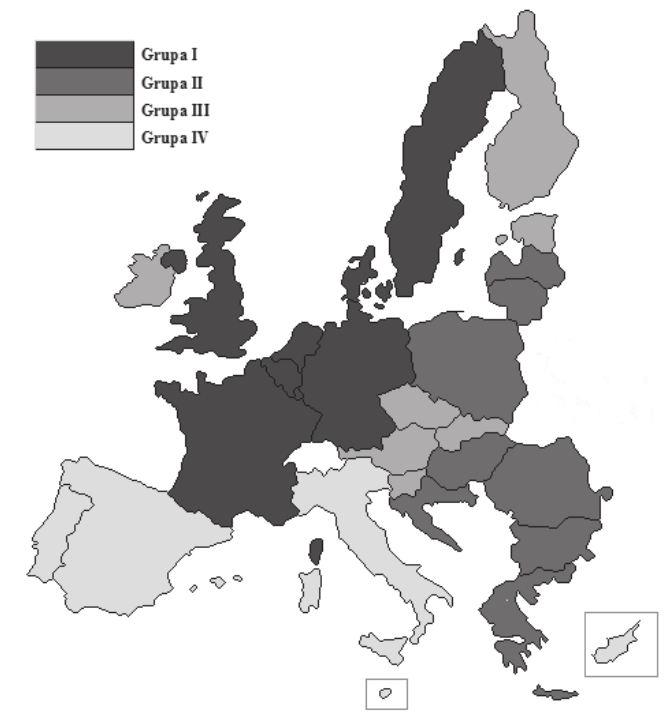

Rys.7. Zróżnicowanie państw UE pod względem wskaźników charakteryzujących zatrudnienie i intensywność W rolnictwie - grupy typologiczne (skupienia)

Fig. 7. Diversification of EU member states in terms of indicators characterizing the employment and intensity in agriculture - typological groups (clusters)

Źródło: obliczenia własne. 
Grupe III utworzyło siedem państw tj.: Czechy, Estonia, Irlandia, Austria, Słowenia, Słowacja oraz Finlandia. W państwach tej grupy zaobserwowano najniższy wśród wydzielonych grup udział zatrudnionych o niskim wykształceniu w rolnictwie w czynnych zawodowo ogółem. Ponadto grupa ta charakteryzuje się niższym od średniej dla całego badanego obszaru udziałem zatrudnionych w rolnictwie, który nie przekroczył 3,5\%. Na poziomie średniej $\mathrm{w}$ tej grupie odnotowano udział wartości dostarczanej przez sektor pierwszy, który ukształtował się na poziomie $2,3 \%$ oraz ekonomiczną wielkość gospodarstw, która wyniosła 62,0 SO/gospodarstwo w EUR. Natomiast poniżej średniej w tej grupie ukształtowała się produktywność pracy w rolnictwie, która osiagnęła 13,1 tys. EUR/AWU.

Ostatnią IV grupę utworzyło pięć państw, tj.: Hiszpania, Włochy, Cypr, Malta oraz Portugalia. Cechą charakterystyczną tej grupy jest najwyższy ze wszystkich grup udział zatrudnionych $\mathrm{w}$ rolnictwie o niskim wykształceniu wśród ludności czynnej zawodowo, który ukształtował się na poziomie $74,6 \%$, przewyższając ponad dwukrotnie średnią dla całego badanego regionu. Ponadto państwa tej grupy cechują się dość niską ekonomiczną wielkością gospodarstw na poziomie 24,4 SO/gospodarstwo w EUR. Jest to wartość prawie trzykrotnie niższa od średniej dla całego badanego regionu. Natomiast pozostałe przyjęte do badań cechy tj.: udział zatrudnionych w rolnictwie, produktywność pracy w rolnictwie, udział wartości dodanej dostarczanej przez pierwszy sektor oraz udział użytków rolnych zarządzanych przez gospodarstwa o dużej intensywności na ha ukształtowały się na poziomie zbliżonym do wartości średniej dla całego badanego obszaru.

\section{Dyskusja}

Jak podkreśla Baer-Nawrocka (2017) doświadczenia wielu państw europejskich pokazują że wraz z rozwojem gospodarczym sektor rolny zmienia swój tradycyjny charakter na bardziej przemysłowy. Dzieje się to przy jednoczesnym zmniejszeniu roli rolnictwa $\mathrm{w}$ gospodarce narodowej mierzonej udziałem w tworzeniu PKB i zatrudnieniu. $Z$ reguły im kraj wyżej rozwinięty pod względem społeczno-gospodarczym tym niższy udział rolnictwa w gospodarce narodowej, jak i w strukturze zatrudnienia (GodlewskaMajkowska, 2009). Nie oznacza to marginalizacji rolnictwa, gdyż pełni ono ważne funkcje: gospodarcze, społeczne i ekologiczne (Grudzińska, Krynicka-Tarnacka, 2003; Szczukocka, 2012). Warunkiem spełnienia tych funkcji jest jednak inicjowanie nowych rozwiazań technicznych, technologicznych i organizacyjnych, sprzyjających jak najlepszemu zaspokojeniu potrzeb ludzi (Godlewska-Majkowska, 2009).

Wskazuje się na duże zróżnicowanie państw Unii Europejskiej zarówno pod względem zatrudnienia i kosztów pracy w rolnictwie (Employment in European Agriculture, 2014), jak i w zakresie intensywności i produktywności (Baráth, Fertő, 2016). Jednocześnie należy dodać, że oba procesy w ujęciu dynamicznym podlegają pozytywnym zmianom (Productivity in EU agriculture - slowly but steadily growing, 2016).

W perspektywie długookresowej efektem przemian, które zachodzą w sektorze rolnym jest głównie poprawa produktywności rolnictwa, która pozwala na przeniesienie zasobów do sektorów o wyższej wydajności. Zdaniem Parzonko (2016) zasoby pracy odgrywają bardzo ważną rolę $\mathrm{w}$ procesie produkcji rolniczej, jednak ich nadwyżka może stanowić problem. Jak podkreśla Woś (2004) wzrost konkurencyjności wytwarzanych produktów, poprawa wydajności pracy i relacji pomiędzy czynnikami produkcji, szczególnie 
w odniesieniu do rolnictwa, może dokonać się głównie przez redukcję stanu zatrudnienia. $\mathrm{W}$ rezultacie spowoduje to wzrost produktywności w całej gospodarce narodowej. Końcowym efektem tego procesu jest wysoka produktywność rolnictwa o niskim udziale pracujących w gospodarce narodowej ogółem (Baer-Nawrocka 2017). Z tego powodu realizacja Wspólnej Polityki Rolnej jest szczególnie ważna dla państw środkowowschodniej części Europy, gdyż może przyczynić się do zmian strukturalnych w ich rolnictwie (Dzun, 2012).

Analizując intensywność rolnictwa należy podkreślić, że Unia Europejska należy do wiodących eksporterów i importerów produktów rolnych na świecie. Jednak warto dodać, że jest to wynikiem wysokiego udziału poszczególnych państw UE w międzynarodowej wymianie, a nie jej globalnej pozycji (Grochowska, 2012). Wśród największych importerów i eksporterów światowych znajdują się, takie państwa Unii Europejskiej jak: Wielka Brytania, Niemcy, Francja, Belgia, Holandia, Włochy oraz Hiszpania (FAO..., 2010). Warto podkreślić, iż są to $\mathrm{w}$ większości kraje, które znalazły się z grupie I przeprowadzonej klasyfikacji.

\section{Podsumowanie}

W związku z coraz większymi wymaganiami związanymi z jakością żywności, odpowiednia intensywność i produktywność rolnictwa, a także odpowiednie wykorzystanie posiadanych czynników produkcji w tym głównie pracy jest niezwykle ważna dla dalszego rozwoju społeczno-gospodarczego. W artykule podjęto próbę omówienia zatrudnienia w kontekście intensywności rolnictwa w państwach Unii Europejskiej na podstawie wybranych cech.

W wyniku przeprowadzonych analiz podzielono kraje UE na cztery grupy zróżnicowane pod względem wskaźników zatrudnienia i intensywności w rolnictwie. Grupa I obejmuje państwa zlokalizowane w centralnej i północnej części Europy, które cechują się wysoką intensywnością rolnictwa oraz niskim poziomem zatrudnienia w rolnictwie i udziałem wartości dodanej dostarczanej przez sektor pierwszy gospodarki. Grupę II utworzyły państwa zlokalizowane we wschodniej części Europy, które charakteryzują się wysokim udziałem ludności zatrudnionej $\mathrm{w}$ rolnictwie i wysokim udziałem wartości dodanej dostarczanej przez pierwszy sektor oraz niską intensywnością rolnictwa. Grupa III obejmuje kraje zlokalizowane w północnej i środkowej części Europy, które charakteryzują się dość niskim poziomem zatrudnienia w rolnictwie oraz średnią intensywnością rolnictwa. Grupa IV została utworzona przez państwa południowej części Europy, których cechą charakterystyczną jest dość wysoki udział zatrudnionych $\mathrm{w}$ rolnictwie $\mathrm{i}$ bardzo wysoki udział zatrudnionych $\mathrm{w}$ rolnictwie o niskim poziomie wykształcenia oraz niższa niż przeciętna intensywność rolnictwa.

Przeprowadzona analiza potwierdza fakt, iż $\mathrm{w}$ państwach o wysokim poziomie zatrudnienia $\mathrm{w}$ rolnictwie oraz wysokim udziale osób zatrudnionych o niskim poziomie wykształcenia zwykle mniejszy jest udział wartości dodanej dostarczanej przez sektor pierwszy gospodarki oraz charakteryzują się mniejszą intensywnością rolnictwa. Natomiast $\mathrm{w}$ państwach o niższym udziale zatrudnionych $\mathrm{w}$ rolnictwie $\mathrm{i}$ niewielkim udziale zatrudnionych o niskim poziomie wykształcenia intensywność rolnictwa jest $\mathrm{z}$ reguły zdecydowanie większa. Zróżnicowanie to wynika także $\mathrm{z}$ różnic historycznych kształtujących sytuację w rolnictwie poszczególnych państw. 


\section{Literatura}

Agriculture, forestry and fishery statistics -2017 edition. (2017). Eurostat, Luxemburg.

Baer-Nawrocka, A. (2017). Wydajność pracy w rolnictwie krajów Unii Europejskiej (ujęcie dynamiczne) (Labour Productivity in Agriculture of European Union Countries (Dynamic Approach)). Prace Naukowe Uniwersytetu Ekonomicznego we Wrocławiu, 489, 24-33.

Baráth, L., Fertő, I. (2016). Productivity and Convergence in European Agriculture, Institute Of Economics, Centre for Economic and Regional Studies. Hungarian Academy of Sciences, MT-DP, 26, 16-26.

Bielecki, S. (2010). Wspólna Polityka Rolna (Common Agricultural Policy). W: Kompendium wiedzy o Unii Europejskiej. Wydawnictwo Naukowe PWN, Warszawa.

Dzun, W. (2012). Gospodarstwa rolne po wejściu do UE. Analiza zmian strukturalnych na tle lat poprzednich (Farms after joining the EU. Analysis of structural changes against the background of previous years). W: Uwarunkowania ekonomiczne polityki rozwoju polskiej wsi i rolnictwa, M. Drygas, K. Zawalińska red. nauk., IRWiR PAN, Warszawa.

Employment in European Agriculture: Labour Costs, Flexibility and Contractual Aspects (2014). Project Report, Institut der deutschen Wirtschaft Köln, Cologne.

European Commission (2017). Cap context indicators 2014-2020, Agriculture and Rural Development.

FAO Statistical Yearbook 2010 (2010). FAO, Rzym.

Głowacki, M. (2002). Regionalne zróżnicowanie intensywności rolnictwa w Polsce (Regional diversification of agricultural intensity in Poland). Pamiętnik Puławski, 130/1, 213-221.

Godlewska-Majkowska, H. (2009). Produkcja rolna (Agricultural production). W: Geografia ekonomiczna pod red. K. Kuciński. Oficyna a Wolters Kulwer business, Kraków, 227-229.

Grochowska, R. (2012). Możliwości rozwoju rolnictwa unijnego w wyniku zmian Wspólnej Polityki Rolnej po 2013 roku (Prospects for EU agricultural development as a result of post-2013 CAP changes). Problemy Rolnictwa Światowego, 12(1), 75-82.

Grudzińska, D., Krynicka-Tarnacka, T. (2003). Geografia. Świat i Polska. System społeczno-gospodarczy (Geography. World and Poland. Socio-economic system). Stowarzyszenie Oświatowców Polskich, Toruń.

Kasztelan, P. (2008). Intensywność produkcji a efektywność ekonomiczna wielkoobszarowych przedsiębiorstw rolniczych (Production Intensity and Economic Efficiency of Large Agricultural Enterprises). Roczniki Nauk Rolniczych, Seria G, 95 (1), 85-94.

Kwiatkowski, E. (1980). Teoria trzech sektorów (Theory of three sectors). PWN, Warszawa.

Parysek, J., Wojtasiewicz, L. (1979). Metody analizy regionalnej i metody planowania regionalnego (Methods of regional analysis and regional planning). PWN, Warszawa.

Parzonko, A. (2016). Rezerwy zasobów pracy w rolnictwie w Polsce i możliwości ich wykorzystania (Reserves of labour resources in agriculture in poland and the possibilities to use them), RN SERiA, 18(3), 292-297.

Productivity in EU agriculture - slowly but steadily growing (2016). European Commission, EU Agricultural Markets, 10, 1-19.

Sienkiewicz, M.W. (2009). Znaczenie Wspólnej Polityki Rolnej Unii Europejskiej dla rozwoju rolnictwa i obszarów wiejskich w Polsce (The importance of the Common Agricultural Policy of the European Union for the development of agriculture and rural areas in Poland). W: Polska w Unii Europejskiej - Problemy i doświadczenia procesu integracji, T. Połaszewska-Rejdl, T. Szot-Gabryś red. nauk., WSU w Kielcach.

Skrzypczak, W. (2002). Geografia ekonomiczna z rozszerzoną geografią fizyczną (Economic geography with extended physical geography). Efekt, Warszawa.

Szczukocka, A. (2012). Poziom i dynamika zmian zatrudnienia w sektorze rolnym w Polsce na tle innych państw Unii Europejskiej (Size and Changes of Employment in the Agricultural Sector in Poland Against a Background of These in the Other EU Member States), Problemy Rolnictwa Światowego, 12(2), 114-122.

Woś, A., (2004). W poszukiwaniu modelu rozwoju polskiego rolnictwa (In search of a model for the development of Polish agriculture). Wydawnictwo IERiGŻ-PIB, Warszawa.

Do cytowania / For citation:

Ossowska L., Janiszewska D. (2018). Zatrudnienie a intensywność rolnictwa państw Unii Europejskiej. Problemy Rolnictwa Światowego, 18(3), 238-247; DOI: 10.22630/PRS.2018.18.3.82

Ossowska L., Janiszewska D. (2018). Employment and Intensity of Agriculture of European Union Countries (in Polish). Problems of World Agriculture, 18(3), 238-247;

DOI: 10.22630/PRS.2018.18.3.82 